\title{
МЕТОД ДИАГНОСТИКИ ПРИ РАЗРАБОТКЕ СОСТАВОВ И СПОСОБОВ МОДИФИКАЦИИ ДИСПЕРСНЫХ СИСТЕМ НА ОСНОВЕ АЛЮМИНИЯ
}

Шевченко В.Г., Еселевич Д.А., Конюкова А.В.

ФГБУН Институт химии твердого тела УрО РАН, Екатеринбург, Россия

shevchenko@ihim.uran.ru

DOI: 10.26902/ASFE-11_67

Порошкообразный алюминий находит все более широкое применение в различных областях науки и техники. Основными сферами использования являются металлургия, машиностроение, производство взрывчатых веществ различного назначения. В работах, на примерах разработки алюминиевых порошков повышенной реакционной способности, модифицированных порошков для традиционных методов порошковой металлургии и составов для инновационной области производства изделий методом 3Д печати, показана эффективность совместного использования термоаналитических методов (ДТА, ДСК, ТГ), масс-спектрометрии, рентгеновского фазового анализа in situ c применением источника синхротронного излучения [1-4].

Преимущества перечисленных аналитических методов состоит в возможности получения информации непосредственно в процессе протекания процессов, определяющих сферы их практического применения, либо в условиях близких к реальным.

\section{Сиисок литературы}

1. Пат. РФ № 2509790. Способ активации порошка алюминия / В.Г. Шевченко, Д.А. Еселевич, А.В. Конюкова, В.Н. Красильников. Опубл. 20.03.2014. Бюл. № 8.

Шевченко В.Г., Еселевич Д.А., Попов Н.А. [и др.]. Окисление порошка АСД-4, модифицированного $\mathrm{V}_{2} \mathrm{O}_{5} / /$ Физика горения и взрыва, 2018, 54 (1), 65-71.

2. В.Г. Шевченко, В.Н. Красильников, Д.А. Еселевич, А.В. Конюкова. Окисление порошкообразного алюминия после модификации поверхности формиатами $\mathrm{Mn}$, Fe, Co и $\mathrm{Ni} / /$ Физикохимия поверхности и защчита материалов, 2019, 55 (1), 25-32.

3. В.Г. Шевченко, Д.А. Еселевич, Н.А. Попов [и др.]. Физико-химические исследования порошка Al-Сu и материала на его основе, полученного в неоптимальных условиях 3Д-печати // Физикохимия поверхности $u$ защитта материалов, 2019, 56 (4), 362-368.

Работа выполнена в соответствии с государственным заданием Института химии твердого тела УрО РАН № AAAA-A19-119031890028-0. 